ELŻBIETA ZNAMIEROWSKA-RAKK

Warszawa

\title{
IDEA NARODOWA W KONFRONTACJI \\ Z ZAMYSŁAMI WSPÓLNOTOWYMI. PRZYKŁAD JUGOSŁAWII
}

Na tle wielce skomplikowanej i zróżnicowanej mapy politycznej środkowo-wschodniej części naszego kontynentu po I wojnie światowej warto przybliżyć fenomen narodzin państwa jugosłowiańskiego w $1918 \mathrm{r}$. Warto co najmniej z kilku powodów. Przede wszystkim dlatego, że stanowi on pierwsze zwieńczenie długoletnich starań o stworzenie zjednoczonego państwa narodów południowosłowiańskich, przebiegających zarówno w aspekcie koncepcyjnym, jak w realizacyjnym (abstrahuję od państwa Słoweńców, Chorwatów i Serbów, które było jedynie kilkutygodniową efemerydą, powstałą na gruzach monarchii Austro-Węgier). Po wtóre, fenomen ten dotyczy Bałkanów - regionu, który niemalże przez cały $\mathrm{XX}$ w. pozostawał w centrum opinii międzynarodowej. Wszak tutaj latem 1914 r. doszło do wybuchu konfliktu światowego, poprzedzonego częstymi zrywami powstańczymi, krwawymi przewrotami władzy, dyktaturami i lokalnymi wojnami z lat 1912-1913, co przydało Bałkanom miano „kotła bałkańskiego” czy „beczki prochu”. Z kolei realia, jakie ukształtowały świat po II wojnie światowej, doprowadziły do ostrej polaryzacji regionu bałkańskiego na strefę komunizmu i „,wolnego świata”. W rezultacie okres od 1945 r. do upadku systemu komunistycznego w Europie w 1989 r. upływał pod znakiem konfrontacji na linii Wschód-Zachód czyli zimnej wojny, w której Bałkany, ze względu na położenie geostrategiczne w pobliżu cieśnin czarnomorskich i wschodniej części Morza Śródziemnego, stanowiły jeden z najbardziej newralgicznych obszarów w wymiarze kontynentalnym i globalnym. Wreszcie bałkańska pożoga wojenna w ostatnim dziesięcioleciu wieku XX przypieczętowała przeświadczenie 
opinii międzynarodowej o narodach owego regionu jako chronicznie skonfliktowanych i zdolnych do barbarzyńskich działań.

Analizując najnowsze dzieje narodów południowosłowiańskich nie sposób jednak twierdzić, iż w stosunkach między nimi zawsze panował duch wrogości czy ostrej konfrontacji. Należy bowiem wskazać nie tylko na utworzenie czterech postaci jugosłowiańskiej struktury państwowej: królewskiej Jugosławii (1918-1941), komunistycznej federacji (19451991), tzw. trzeciej Jugosławii, złożonej już wyłącznie z Serbii i Czarnogóry (1992-2003) oraz jej sukcesorki pod nazwą Wspólnota Państwowa Serbia i Czarnogóra, stanowiącej efemeryczną konfederację tych państw (2003-2006). Również należałoby podkreślić liczne i różnorakie koncepcje zmierzające do integracji Słowian południowych.

W poszukiwaniu korzeni elementów spajających południowych Słowian, zamieszkujących zachodnie Bałkany, należałoby cofnąć się do bardziej odległej przeszłości. Przypomnijmy, że na przestrzeni dziejów Bałkany pozostawały pod panowaniem imperiów: rzymskiego, bizantyjskiego, osmańskiego i habsburskiego, a zamieszkująca ten region ludność doznawała z ich strony dotkliwego ucisku politycznego, ekonomicznego i kulturalno-religijnego. Ucisku usprawiedliwianego przez zaborcze reżimy bądź to ich wyższością cywilizacyjną, bądź supremacją duchową. Taki stan rzeczy (także wówczas, gdy obszar ten został zasiedlony przez Słowian) rodził opór i parcie uciskanej ludności do walki przeciwko jarzmu zaborców, co jednocześnie stymulowało procesy narodowotwórcze, które na Bałkanach pojawiły się już w końcu XVII i w XVIII w. W tym okresie doszło do odrodzenia idei narodowej poszczególnych nacji bałkańskich. W rezultacie prowadziło to w obrębie danej nacji do świadomej samoidentyfikacji i konsolidacji narodowej, zapoczątkowując walkę narodowowyzwoleńczą, a w miarę jej sukcesów przemyśliwano również o tworzeniu struktur narodowej państwowości.

Serbskie odrodzenie narodowe zostało zainicjowane przez Serbów węgierskich na terytorium Pogranicza Wojskowego, a głównie przez tamtejszą autonomiczną Cerkiew prawosławną, która dzięki podtrzymywaniu tradycji historycznych, pielęgnowaniu zabytków piśmiennictwa i kultury serbskiej stała się zaczątkiem ruchu odrodzeniowego Serbów. Należy przy tym wskazać na różnice cywilizacyjne pomiędzy Serbami, żyjącymi w monarchii habsburskiej, a ich pobratymcami z Serbii właściwej, usytuowanej za Sawą i Dunajem, będącej ówcześnie pod władzą imperium osmańskiego. Lecz chociaż ci drudzy pozostawali na niższym poziomie kultury, to jednak cechowała ich ogromna waleczność i silna determinacja państwowotwórcza, dzięki której stworzyli zręby własnej 
państwowości w postaci Księstwa Serbskiego. Naturalnie jeszcze pozbawionego atrybutów suwerenności.

Z kolei ruch iliryjski, jako chorwacki ruch odrodzeniowy, zapoczątkowany w trzeciej dekadzie XIX w., dał Chorwatom kodyfikację języka, dokonaną przez Ljudevita Gaja, i stworzył podstawy ich programu integracji narodowej. Ruch iliryjski jednak nie zyskał aprobaty ani Słoweńców, ani Serbów. Podczas gdy Gaj budował zręby ideologii iliryzmu, Vuk Karadžić wygenerował nowe pojęcie narodu serbskiego na bazie kryterium językowego. Głosił on, że wszyscy mówiący dialektem sztokawskim są Serbami. Dialekt ten, równocześnie wybrany przez Gaja jako podstawa języka iliryjskiego, stanowił ważną przesłankę językowego zbliżenia Serbów i Chorwatów i zarazem symbol potencjalnej ich jedności. Wszakże do realizacji owego projektu ostatecznie nie doszło, gdyż przywódcy obu tych narodów w planowanej wspólnocie nieustępliwie przewidywali dla nich pozycję dominującą.

Najbardziej przeniknięte dominacją serbskości były idee federacyjne lansowane przez Serbów z Księstwa Serbii. Wśród tych zamysłów na uwage przede wszystkim zasługuje plan stworzenia wielkiego państwa południowosłowiańskiego, opracowany przez wybitnego serbskiego polityka, Iliję Garašanina. W opracowanym przez niego w $1844 \mathrm{r}$. słynnym dziele, którego tytuł Načertanije (Szkic, Zarys) stał się synonimem doktryny panserbizmu, zostały zawarte główne założenia wielkoserbskiej idei narodowej. Garašanin nawiązywał do świetności średniowiecznego państwa Serbów za panowania cara Stefana Dušana. Ponadto eksponował fakt, że naród serbski był pierwszą nacją na Bałkanach, która zdołała zbudować własną państwowość, pomimo prężnego tam jeszcze panowania osmańskiego. Argumentacja ta była skwapliwie wykorzystywana przez kolejne pokolenia serbskich elit politycznych jako uzasadnienie tezy o historycznie ugruntowanej predestynacji Serbów do sięgnięcia po przywództwo w projektowanych związkach państwowych narodów bałkańskich. Wizerunek swoistego mesjanizmu Serbii wobec nich przechodził z pokolenia na pokolenie, utrwalając autostereotyp wyjątkowych cnót i wybraństwa żywiołu serbskiego.

Okres Wiosny Ludów 1848-1849 stanowił ważną cezurę w kształtowaniu się świadomości narodowej i programów politycznych Słowian habsburskich. Jednym z nich był tzw. austroslawizm - projekt sprowadzający się do konsolidacji bliskich sobie etnicznie Słowian w jednym państwie federacyjnym pod nazwą Wielka Iliria. Wskazywało na to, wbrew dominującej narracji o austroslawizmie jako projekcie czeskich przywódców duchowych, wsparcie, jakie otrzymywali poddani dworu wiedeńskiego jako Ilirowie, za których słowiańscy ideolodzy uznawali 
Serbów, Chorwatów, Słoweńców, Bośniaków, Czarnogórców i Bułgarów. Wszakże największą ułomnością owej koncepcji było promowanie li tylko autonomii owego zjednoczonego tworu państwowego w ramach imperium Habsburgów. W latach sześćdziesiątych XIX w. wśród chorwackich działaczy niepodległościowych pojawiły się dwa nowe nurty: jugoslawizm i prawasztwo. Początkowo liderzy jugoslawizmu akcentowali potrzebę stworzenia duchowej jedności Słowian południowych, a dopiero potem optowali za zbudowaniem jugosłowiańskiej wspólnoty państwowej. Stymulacja idei zjednoczeniowej nastąpiła w latach 1866-1867, kiedy to ważyły się losy i kształt monarchii habsburskiej. Obawy przed dualizmem austriacko-węgierskim spowodowały zacieśnienie wzajemnych stosunków Chorwatów i Słoweńców oraz także Serbów. W latach siedemdziesiątych XIX stulecia, w dobie zagrożenia niemieckiego po wojnie francusko-pruskiej, doszło do wyraźnego ocieplenia relacji serbsko-chorwackich. $\mathrm{W}$ rezultacie politycy wywodzaccy się $\mathrm{z}$ owych trzech pobratymczych nacji lansowali program, którego celem miało być zjednoczenie Serbów, Chorwatów i Słoweńców w niezależnej, wolnej, narodowej jugosłowiańskiej strukturze państwowej.

Wkrótce jednak nastąpiło zderzenie idei narodowej Serbów i Chorwatów w okresie wielkiego kryzysu bałkańskiego 1875-1878 na tle sporu o przynależność Bośni i Hercegowiny. Serbowie, traktując Bośnię i Hercegowinę jako z natury rzeczy należny im obszar, oskarżali chorwackich i słoweńskich działaczy narodowych o zdradę interesów Słowian południowych, co doprowadziło do silnego zaognienia ich wzajemnych stosunków. W latach osiemdziesiątych obok Partii Narodowej duże znaczenie na scenie politycznej Chorwacji zyskała Chorwacka Partia Prawa (prawasze), która optowała za utworzeniem Wielkiej Chorwacji. Ten kierunek programowy w skrajnej postaci kontynuowała, wyłoniona z owej partii frakcja tzw. Czystej Partii Prawa. Przywódca jej - Josip Frank - stał bowiem na pozycjach antyserbskich i jawnie wielkochorwackich, patronując koncepcji trializmu, zakładającej ukonstytuowanie trzeciego segmentu monarchii Austro-Węgier pod egidą Chorwacji, który miał obejmować takie terytoria, jak Chorwację ze Slawonią, Słowenię, Dalmację oraz Bośnię i Hercegowinę.

Tymczasem serbska Partia Narodowo-Radykalna lansowała ideę wielkoserbską, co na przełomie lat 1902/1903 tak dalece zantagonizowało Serbów i Chorwatów habsburskich, iż nie powstrzymywali się nawet przed wzajemnymi krwawymi utarczkami. Jednakże już w 1905 r., pomimo trwającej wrogości, doszło do ponownego ich zbliżenia, przypieczętowanego podpisaniem rezolucji w Rijece i Zadarze dotyczącej zawarcia koalicji serbsko-chorwackiej. Wskazywało to na renesans idei jugosłowiańskiej, 
gdyż w myśl owego porozumienia po upadku Austro-Węgier planowano zbudowanie wspólnego państwa federacyjnego Chorwatów i Serbów. Trzeba przy tym pamiętać, że Serbia mocą zapisów traktatu berlińskiego z 1878 r. uzyskała pełną suwerenność. Ponadto w 1882 r. proklamowała Królestwo, a po przewrocie władzy w 1903 r. nowe władze serbskie związały się z Rosją i przyjęły w polityce zagranicznej opcję antyhabsburską. Wszystko to, oraz sukcesy Serbów na polach bitewnych wojen bałkańskich i przy stole konferencyjnym po ich zakończeniu, niewątpliwie wzmacniało pozycję Serbii na Bałkanach, predestynując ją do objęcia przywództwa w procesie zjednoczeniowym Słowian południowych.

Ten stan rzeczy potwierdziły wydarzenia ściśle związane z przebiegiem i skutkami I wojny światowej. W tym okresie bowiem idea zjednoczenia jugosłowiańskiego nabierała coraz bardziej realnego kształtu. Ponadto należy zauważyć, że sama bezpośrednia przyczyna wybuchu tego konfliktu dotyczyła kwestii jugosłowiańskiej. Mam tutaj na myśli zamach na następcę tronu Austro-Węgier Franciszka Ferdynanda, dokonany w czerwcu 1914 r. w Sarajewie przez młodych Serbów bośniackich, walczących o przyłączenie Bośni do Serbii. Dla Wiednia było oczywiste, że za zamachowcami stały serbskie czynniki rządzące, co stanowiło powód wypowiedzenia Serbii wojny. W reakcji na ten akt Belgrad ogłosił, iż armia serbska będzie walczyła o wyzwolenie i zjednoczenie nie tylko wszystkich Serbów (a zatem także Serbów habsburskich), ale również „braci Chorwatów i Słoweńców" z Austro-Węgier. Całkiem inaczej po wybuchu I wojny światowej zachowały się partie skupiające Słowian południowych w monarchii habsburskiej. Otóż w początkowym okresie przestrzegały one zasad lojalności wobec władz monarchii Habsburgów, przejawiając pewną rezerwę w stosunku do zmagań wojennych Serbów i Czarnogórców. Część czołowych polityków: Chorwatów, Serbów i Słoweńców znalazła się na emigracji, gdzie w końcu kwietnia 1915 r. utworzono Komitet Jugosłowiański z siedzibą w Londynie pod przewodnictwem Ante Trumbicia - Chorwata z Dalmacji. Jako reprezentacja Słowian południowych Austro-Węgier organizacja ta rozwinęła aktywną działalność polityczną i propagandową. Fundamentalnym celem, który przyświecał Komitetowi Jugosłowiańskiemu w początkach jego działalności, było udaremnienie realizacji tajnej umowy podpisanej przez mocarstwa Ententy z Rzymem w kwietniu 1915 r. Postanowienia owego dealu miały bowiem skrajnie niekorzystną wymowę dla Słowian południowych, ponieważ przyznawały Włochom znaczące terytoria zamieszkane przez Chorwatów, Słoweńców i Serbów pod panowaniem austro-węgierskim. W dążeniu do wzmocnienia swych nadwątlonych na froncie przeciwko armii państw centralnych sił Ententa nakłoniła Włochy do przystąpienia do wojny po jej stronie 
w zamian za przyłączenie nabytków terytorialnych - Istrii, Rijeki, Triestu i znaczącej części Dalmacji, wysp dalmatyńskich i części Albanii, a także niektórych miejscowości usytuowanych w Słowenii. Zapisy te również godziły w interesy Serbii i Czarnogóry, które niewątpliwie ucierpiałyby wskutek ekspansji włoskiej na wschodnim wybrzeżu Adriatyku po przewidywanym demontażu monarchii habsburskiej i przejęciu po niej schedy przez Słowian habsburskich. Lecz taki scenariusz jeszcze się nie urzeczywistnił, gdyż cesarz Karol I po śmierci Franciszka Józefa usiłował ratować upadającą monarchię, zapowiadając reformy państwa i uwzględnienie aspiracji niepodległościowych narodów słowiańskich. W odpowiedzi na te deklaracje w maju 1917 r. w ramach Klubu Jugosłowiańskiego w parlamencie wiedeńskim w imieniu posłów chorwackich, serbskich i słoweńskich Anton Korošec, przywódca Słoweńskiej Partii Ludowej, ogłosił deklarację o potrzebie zjednoczenia wszystkich zamieszkałych przez nich ziem w niezależny organizm państwowy, lecz pod berłem Habsburgów.

Deklaracja Klubu Jugosłowiańskiego, stojąca na stanowisku niezależności Słowian habsburskich, ale bez zrywania więzi z monarchią austro-węgierską, a także zagrożenie ekspansją Rzymu na wschodnim wybrzeżu Adriatyku zintensyfikowały współpracę rządu serbskiego i Komitetu Jugosłowiańskiego, co zaowocowało podpisaniem 20 lipca 1917 r. oświadczenia, stanowiącego jeden z pierwszych dokumentów zapowiadających utworzenie wspólnego państwa jugosłowiańskiego. Ostatecznie ustalono, że planowane wspólne państwo - Królestwo Serbów, Chorwatów i Słoweńców pod berłem dynastii serbskiej Karadziordziewiciów obejmie cały obszar zamieszkany przez „nasz trójimienny naród” łącznie z Czarnogórą. A zatem podstawą integracji miał być program jugosłowiański, a nie wielkoserbski czy wielkochorwacki.

Dalszy rozwój wydarzeń na frontach wojennych po wycofaniu się Rosji, a zwłaszcza po przystąpieniu do wojny Stanów Zjednoczonych, zdawał się przyspieszać upadek monarchii austro-węgierskiej i otwierać drogę do uzyskania pełnej suwerenności przez Słowian habsburskich. Jednakże bezpośrednio na realizację tego celu wpłynął nasilający się jesienią 1918 r. kryzys monarchii austro-węgierskiej. W tych realiach 6 października w Zagrzebiu powołano Radę Narodową Słoweńców, Chorwatów i Serbów na czele z Korošecem, a 29 października proklamowano niepodległe i demokratyczne państwo Słoweńców, Chorwatów i Serbów (SHS), obejmujące ziemie jugosłowiańskie w Austro-Węgrzech.

Wszelako droga do zjednoczenia państwa SHS z Serbią na zasadach partnerstwa najeżona była wieloma przeszkodami. Przede wszystkim władze młodego organizmu państwowego nie były w stanie uporać się 
z ogromnymi trudnościami wewnętrznymi. Brak żywności, bezrobocie, wszechobecny chaos, niedostatek struktur terenowych i środków finansowych groziły wybuchem niezadowolenia i buntu społecznego. Co gorsza, pojawiło się także realne zagrożenie zewnętrzne ze strony Włoch, których siły militarne gotowe były do zajmowania ziem państwa SHS, przyobiecanych im przez Ententę. W sytuacji dysponowania zaledwie kilkoma oddziałami żołnierzy z byłej armii austro-węgierskiej, nieliczną strażą i policją, jedyną nadzieję władz nowo powstałego organizmu państwowego na zażegnanie tych niebezpieczeństw stanowiło połączenie z Serbią. Jednakże w łonie czynników rządzących w Zagrzebiu wystąpiły poważne różnice zdań co do tego, kiedy i w jaki sposób należało ten palący problem rozwiązać. Grupa polityków w kołach rządowych SHS tzw. centralistów, którzy byli przeważnie Serbami, głosiła konieczność niezwłocznego i bezwarunkowego zjednoczenia z Królestwem Serbii. Natomiast tzw. federaliści - głównie Chorwaci i Słoweńcy wraz z Korošcem - stali na stanowisku stworzenia wspólnego państwa funkcjonującego na zasadzie dwóch równoprawnych członów, a nie inkorporacji, a tak oceniali opcję reprezentowaną przez centralistów. A zatem, nieserbska część polityków we władzach w Zagrzebiu uznawała konieczność unii z Serbią, ale na warunkach udaremniających serbską dominację. Kierowano się przeświadczeniem, że wyższość kulturowa i ekonomiczna Chorwatów i Słoweńców oraz ich ściślejsze związki z cywilizacją zachodnią aniżeli z Bałkanami winny zapewnić państwu SHS przynajmniej partnerstwo w związku z Serbią. Na początku listopada 1918 r. pod wpływem rosnącego zagrożenia włoskiego i w Zagrzebiu, i w Belgradzie torowało sobie drogę stanowisko kompromisowe. Pod presją opozycji, rząd serbski premiera Nikoli Pašicia skłonny był do pewnych ustępstw wobec Rady Narodowej państwa SHS. W rezultacie 9 listopada Pašić, Korošeć i Trumbić podpisali tzw. deklarację genewską, określającą zasady funkcjonowania projektowanego organizmu państwowego. Znaczenie fundamentalne w tym akcie miało przyjęcie struktury dualistycznej państwa. A zatem porozumienie genewskie było kompromisem o charakterze przejściowym, zapewniającym każdej ze stron zachowanie władzy suwerennej na swoim terytorium. Jednakże spotkało się ono z dezaprobatą serbskich kół rządzących i dworu, co skutkowało odmową ratyfikacji owego aktu. Również negatywne stanowisko wobec deklaracji zajęli Serbowie chorwaccy.

Tymczasem sytuacja wewnątrzpolityczna w państwie SHS coraz bardziej zaostrzała się wskutek nierozwiązanych trudności gospodarczych, nastrojów niezadowolenia społecznego oraz rozdźwięków w Radzie Narodowej SHS pomiędzy Serbami chorwackimi, zwolennikami bezwarunkowej unii z Serbią, a Chorwatami i Słoweńcami, optującymi za autonomią 
we wspólnym państwie. Równocześnie położenie międzynarodowe młodego państwa południowosłowiańskiego wobec braku jego uznania przez mocarstwa Ententy i podjęcia przez Włochy działań zmierzających do zaanektowania terytoriów przyobiecanych im przez Londyn i Paryż stawało się coraz bardziej krytyczne. Do końca listopada 1918 r. wojska włoskie opanowały Rijekę, Istrię, Triest, Zadar i wiele mniejszych portów Dalmacji, a także wiele miejscowości Słowenii. Pojawiły się także roszczenia terytorialne ze strony pokonanych w wojnie Austriaków i Węgrów. To bezpośrednie zagrożenie suwerenności państwa SHS zmusiło Radę Narodową do szukania pilnej pomocy w Belgradzie, gdyż bezzwłoczne połączenie z Serbią na warunkach strony serbskiej, znacznie gorszych od deklaracji genewskiej, stało się potrzebą chwili. W Zagrzebiu wierzono, że tylko armia serbska mogłaby doprowadzić do zatrzymania włoskiej agresji, a co więcej, Serbia znalazła się w gronie zwycięskiej Ententy, decydującej o ładzie narodowościowo-terytorialnym Europy, a przy tym nieuznającej państwa SHS na arenie międzynarodowej. 1 grudnia $1918 \mathrm{r}$. delegacja Rady Narodowej SHS spotkała się z księciem Aleksandrem, regentem Królestwa Serbii, w celu wymiany aktu proklamującego utworzenie zjednoczonego państwa jugosłowiańskiego pod nazwą Królestwo Serbów, Chorwatów i Słoweńców (Królestwo SHS).

Niewątpliwie ów akt, z punktu widzenia interesów państwa SHS, miał charakter kapitulancki. Przewidywał bowiem przede wszystkim, że władza zwierzchnia należy do regenta serbskiego, a władza ustawodawcza do wspólnego parlamentu ze zdecydowaną przewagą posłów reprezentujących Serbów. Akt zjednoczeniowy został przyjęty z entuzjazmem przez nacjonalistów wielkoserbskich i czynniki rządzące w Belgradzie, wywołał też zadowolenie u Serbów w byłym już państwie SHS. Natomiast wśród Chorwatów i Słoweńców niemalże natychmiast po ogłoszeniu aktu zjednoczenia wystąpiła fala niezadowolenia i protestów. W Zagrzebiu i Lublanie dominowała opinia, że podpisanie przez Radę SHS tego rodzaju porozumienia sankcjonuje supremację serbską, gdyż odrzuca nie tylko federację, ale nawet pozbawia autonomii i ochrony państwowo-prawnej gospodarki Chorwacji i Słowenii. Zarzucano Radzie Narodowej SHS, że przekroczyła swe pełnomocnictwa, godząc się na nadmierne ustępstwa na rzecz Serbii, i że zbyt szybko się rozwiązała. Szczególnie krytycznie akt zjednoczeniowy oceniali zwolennicy federacji ze Stronnictwa Prawa oraz Chorwackiej Partii Chłopskiej Stjepana Radicia, a w pozostałych partiach zaznaczyła się ostra polaryzacja pomiędzy centralistami a autonomistami.

A zatem, zjednoczenie, będące skutkiem konieczności chwili, zaistniałej głównie z powodu zagrożenia zewnętrznego, bynajmniej nie przyniosło stabilizacji wewnątrzpolitycznej pierwszego państwa jugosłowiańskiego. 
Konsolidację terytoriów byłego cesarstwa Habsburgów przyłączonych do monarchii Karadziordziewiciów utrudniały niewątpliwie ich znaczące odrębności ekonomiczne, kulturowe czy wyznaniowe. Lecz przede wszystkim uniemożliwiał to wzajemny antagonizm Serbów i Chorwatów. Albowiem ostra konfrontacja nacjonalizmów obu tych narodów prowadziła do permanentnego konfliktu, grożącego wewnętrznym rozbiciem wspólnego państwa. Serbskie koła rządzące wraz z królem Aleksandrem i kamarylą dworską prowadziły politykę unitaryzmu i centralizmu, której ideologicznym uzasadnieniem miała być teoria o serbsko-chorwacko-słoweńskim trójimiennym zintegrowanym narodzie jugosłowiańskim. Lansowana przez establishment belgradzki teoria, kreująca $\mathrm{w}$ istocie sztuczny fenomen etniczny, w praktyce uprzywilejowywała żywioł serbski kosztem społeczności nieserbskiej. Jednocześnie rząd i monarcha odrzucali jakiekolwiek projekty przebudowy Królestwa SHS w duchu federacyjnym czy nawet autonomicznym, lansowane przez liderów partii chorwackich. W konsekwencji życie polityczne w państwie od jego zarania cechowała zaciekła walka partyjna, na porządku dziennym była wzajemna nienawistna propaganda w przestrzeni publicznej, krwawe starcia, morderstwa polityczne i inne akty terroru. Zmagania rządu z opozycją eskalowały niebywale na gruncie Skupsztiny, prowadząc do kryzysu parlamentarnego, którego apogeum stanowiły krwawe zajścia w czerwcu 1928 r. Wówczas to z ręki jednego z posłów serbskich, który oddał kilka strzałów w stronę przedstawicieli Chorwackiej Partii Chłopskiej, zginął wspomniany wyżej przywódca owej partii, Radić. Zamach w Skupsztinie stanowił kulminację wrogości w stosunkach serbsko-chorwackich. W tym stanie rzeczy, kilka miesięcy później król Aleksander wprowadził w państwie reżim autorytarny, oznaczający faktycznie dyktaturę monarchy. Równocześnie zmieniono nazwę państwa na Królestwo Jugosławii oraz podział terytorialny państwa - w miejsce 33 okręgów administracyjnych wprowadzono dziewięć banowin, eliminując nominalnie odrębność ziem chorwackich i słoweńskich. Ponadto w dalszym ciągu władze oficjalnie $\mathrm{w}$ dyskursie publicznym forsowały formułę nieautentycznej, jednej nacji jugosłowiańskiej, wyrażającej się w haśle: „jeden naród, jeden król, jedno państwo”. Jednakże wszystkie te posunięcia, obliczone na ostateczną likwidację tendencji separatystycznych, nie przyczyniały się do stworzenia nowej jugosłowiańskiej tożsamości, wręcz przeciwnie, przepaść pomiędzy Serbami i Chorwatami jeszcze bardziej się pogłębiała.

Przeciwko polityce utrwalania unitaryzmu i zwiększenia centralizmu występowały nie tylko środowiska chorwackie w państwie, ale również za granicą. Najradykalniej w tym kierunku działała emigracja 
separatystów chorwackich, która głosiła potrzebę utworzenia niepodległego państwa chorwackiego. Liderem ich był Ante Pavelić, poseł do Skupsztiny z listy Chorwackiej Partii Prawa i twórca zakonspirowanej terrorystycznej organizacji wojskowej pod nazwą Ustaša (Powstaniec). Głównym jej celem było doprowadzenie do likwidacji wspólnego państwa jugosłowiańskiego drogą akcji terrorystycznych - zamachów i sabotażu, a w następstwie - proklamowanie Niezależnego Państwa Chorwackiego. Realizując ten program, organizacja Ustaša wraz z macedońską emigracją polityczną spod znaku Wewnętrznej Macedońskiej Organizacji Rewolucyjnej (WMRO) przeprowadziła w 1934 r. udany zamach terrorystyczny na króla Aleksandra, przebywającego z wizytą w Marsylii. Wszelako nadzieje Pavelicia i jego współpracowników na zapoczątkowanie dezintegracji Jugosławii okazały się wówczas płonne. W końcu 1939 r. doszło bowiem do ugody serbsko-chorwackiej, co zaowocowało powołaniem do życia wspólnego gabinetu oraz samorządnej prowincji Chorwacji z własnym parlamentem (sabor) i władzą wykonawczą na czele z banem, mianowanym przez monarchę. Jednakże w kwietniu $1941 \mathrm{r}$. doszło do ataku III Rzeszy i jej sojuszników na Królestwo Jugosławii, co położyło mu kres. Choć ugoda Serbów i Chorwatów, osiągnięta w przededniu wybuchu II wojny światowej, zdawała się odsuwać na dalszy plan ich wzajemny, przewlekły konflikt, to jednak niebawem eksplodował on na nowo. Lecz tym razem to Serbowie zostali „postawieni pod ścianą”, gdyż Chorwaci ogłosili swoje tzw. Niezależne Państwo Chorwackie, obejmujące ziemie, na których żyła m.in. ludność serbska. Panujący tam reżim ustaszowski Pavelicia rychło przystąpił do eksterminacji żywiołu serbskiego. Przeciwstawiając się okupantom i ustaszom, Serbowie zorganizowali ruch oporu w postaci oddziałów czetników pod wodzą Dragoljuba Mihailovicia, walczącego pod hasłem przywrócenia po wojnie monarchii. Równocześnie czetnicy przystąpili do rozprawy z armią partyzancką komunistów Josipa Broz-Tity, którzy w swej strategii dążyli do przechwycenia władzy w powojennej Jugosławii. Można powiedzieć, że obraz okupowanych ziem jugosłowiańskich w czasie II wojny światowej sprowadzał się do walki zbrojnej wszystkich ze wszystkimi: ustaszy z czetnikami, czetników z komunistami, ustaszy z partyzantami Tity.

Nie wchodząc w szczegóły genezy i funkcjonowania komunistycznej federacji Jugosławii, należy stwierdzić, iż państwo to, choć proklamowało już w 1943 r. związek sześciu równoprawnych republik, faktycznie przez cały okres swej egzystencji nie było w stanie rozwiązać antagonizmów narodowościowych - przede wszystkim serbsko-chorwackiego czy serbsko-albańskiego - które niemalże od samego początku, w mniejszym lub większym stopniu, wpisywały się w napięcia wewnątrzpolityczne aż do 
krwawego upadku owego tworu państwowego w 1991 r. Po wybiciu się na pełną suwerenność większości republik byłej komunistycznej Jugosławii, jej pozostałość stanowiła federacja Serbii z Czarnogórą, proklamowana w 1992 r. Jednak i to kadłubowe wspólne państwo dotrwało jedynie do 2003 r., kiedy to zostało przekształcone w konfederację, której demontaż nastąpił trzy lata później.

Należy jednoznacznie stwierdzić, że czynnikiem, który przesądził o utworzeniu Królestwa SHS nie była per se idea jugosłowiańska, lecz zaistniałe realia geopolityczne. Bliska perspektywa utraty ważnych terytoriów wschodniego wybrzeża Morza Adriatyckiego, które w znaczącej części zostały już niemalże opanowane przez wojska włoskie, a także niepewne losy północnych ziem, będących przedmiotem zakusów ze strony Wiednia i Budapesztu, odegrały decydującą rolę w narodzinach pierwszego państwa jugosłowiańskiego. Co więcej, niebagatelny wpływ na tak spieszne i bezwarunkowe przyłączenie obszarów zamieszkanych przez Słowian habsburskich do Królestwa Serbii miało także rozpaczliwe położenie wewnątrzpolityczne ich nowo powstałego państwa. Również trzeba mieć tu na względzie oddziaływanie zaraźliwego fermentu rewolucji bolszewickiej, który mógł na tak podatnym gruncie wywołać krwawą rewoltę. $\mathrm{W}$ tym stanie rzeczy nie tylko Serbowie chorwaccy, ale także sami Chorwaci - główni przywódcy polityczni państwa SHS - zlekceważyli stanowisko środowisk konserwatywnych i nacjonalistycznych zwolenników wynegocjowania odpowiednich warunków zjednoczenia z Królestwem Serbii, gwarantujących równorzędną pozycję.

Wydaje się oczywiste, że większość mieszkańców byłego państwa SHS w krótkim czasie po przyjęciu aktu z 1 grudnia 1918 r. zrozumiała, iż trafiła $\mathrm{z}$ deszczu pod rynnę. Znaleźli się oni bowiem w położeniu niewątpliwie gorszym aniżeli za czasów monarchii austro-węgierskiej, gdzie Chorwacja miała status autonomicznego kraju z własnymi organami państwowymi: parlamentem, banem i rządem, wyposażonymi w szerokie kompetencje w zakresie sprawowania zarządu wewnętrznego. W szczególności Chorwaci uznani byli tam ówcześnie za „naród polityczny” ze swoim językiem, sztandarem i herbem, uczestniczyli w parlamencie węgierskim oraz cieszyli się niezależnością finansową, co było niezwykle ważne dla rozwoju gospodarczego. Natomiast w Królestwie SHS Chorwacja wszystko to utraciła. Serbskie koła rządzące nie respektowały bowiem idei jedności jugosłowiańskiej, gwarantującej równoprawną wspólnotę wszystkich narodów w państwie, lecz narzucili mu unitarny charakter, 
skutkujący wielkoserbskim panowaniem, co przejawiało się w niedemokratycznym, centralistycznym systemie władzy i dominacji Serbów.

Tylko powierzchownie patrząc na narodziny Jugosławii w 1918 r., można twierdzić, iż długotrwała i pełna meandrów walka o urzeczywistnienie idei jugosłowiańskiej osiągnęła swój cel, spajając narody Słowian południowych w jeden organizm państwowy. Naturalnie nie sposób zaprzeczyć, że było to doniosłe wydarzenie dla nich samych, całego regionu bałkańskiego, a nawet makroregionu Europy Środkowo-Wschodniej. Wszak powstało państwo wypełniające próżnię polityczną po dekompozycji monarchii Habsburgów i będące jej sukcesorem, lecz jednocześnie wskutek permanentnych sporów i eskalacji wrogości, zwłaszcza pomiędzy Serbami i Chorwatami, wcześniej czy później skazane ono było na upadek. Wprawdzie w przededniu II wojny światowej nastąpiło pewne złagodzenie napięcia we wzajemnych relacjach obu tych narodów, ale nie było to przecież zwieńczeniem jakiegokolwiek procesu dojrzewania obopólnej woli do autentycznej zgody na zbudowanie klimatu jedności i braterstwa. Stanowiło bowiem jedynie doraźną reakcję konsolidacyjną strony chorwackiej i serbskiej na rosnące zagrożenie zewnętrzne. A zatem, analogicznie jak w 1918 r., kiedy to państwo SHS pod presją groźby aneksji jego ziem przez Włochy czy Austrię i Węgry, zostało zmuszone do połączenia z Serbią na niekorzystnych warunkach, tak w 1939 r. przywódcy chorwaccy i władze belgradzkie ustąpiły, zawierając w gruncie rzeczy niesatysfakcjonującą ugodę - jako nieprzemyślany, taktyczny akt. Oznaczało to kontynuację dotychczasowych perturbacji wewnątrzpolitycznych, prowadzących niechybnie do rozpadu Jugosławii.

Analizując powyższe uwarunkowania narodzin pierwszego państwa jugosłowiańskiego w 1918 r., należy stwierdzić jednoznacznie, że w odróżnieniu od Polski, świętującej stulecie odzyskania niepodległości, narody słowiańskie z zachodnich Bałkanów nie mają specjalnych powodów do obchodzenia tej rocznicy w 2018 r. Dotyczy to w zasadzie nie tylko Królestwa SHS/Królestwa Jugosławii, ale także pozostałych trzech wariantów Jugosławii, których funkcjonowanie i kres dobitnie pokazały, iż idea narodowa zawsze była bliższa każdemu południowosłowiańskiemu narodowi i w konfrontacji z ideami wspólnotowymi, na dłuższą metę, zawsze zwyciężała. Idea narodowa, która w przeszłości okazała się mocą burzącą panowanie zaborczych imperiów, dziś, wcześniej czy później staje się siłą konfrontacyjną przeciwstawiającą narody i państwa, co prowadzi do upadku imperialnych, ponadnarodowych koncepcji i pozbawia je trwałej, egzystencjalnej perspektywy. 
Biogram: Elżbieta Znamierowska-Rakk, prof. dr hab., emerytowana profesor Uniwersytetu Warszawskiego. W latach 2007-2017 w Studium Europy Wschodniej UW kierowała specjalizacją bałkańską. W latach 1985-2013 pracowała w Instytucie Historii PAN, gdzie obok działalności naukowo-badawczej zajmowała się edytorstwem. W okresie 2002-2013 przewodniczyła ze strony polskiej Polsko-Bułgarskiej Komisji Historycznej. Zainteresowania naukowe: dzieje najnowsze Europy Środkowo-Wschodniej, a w szczególności narodów i państw bałkańskich. Jest autorką m.in. monografii: Rozwój stosunków Bułgarii z Grecja i Turcja po II wojnie światowej, 1944-1975; Sprawa Tracji Zachodniej w polityce bułgarskiej 1919-1947 czy Federacja Słowian południowych w polityce Bułgarii po II wojnie światowej oraz licznych artykułów i recenzji. Ostatnio opublikowała m.in. Międzymorze. Nadzieje i ograniczenia w polityce II Rzeczypospolitej, Warszawa 2016 (pod patronatem Ministra Spraw Zagranicznych RP). 